\title{
EFFECT OF ENVIRONMENTAL TEMPERATURES ON PRODUCTION AND BREAD CHARACTERISTICS OF FOUR BREAD WHEAT CULTIVARS
II. BREAD QUALITY ATTRIBUTES AS A FUNCTION OF ENVIRONMENTAL TEMPERATURES PRODUCTIVITY

Abo El-Naga, M. M. ${ }^{1}$ and Hoda M. El-Gharbawy ${ }^{2}$

1) Bread and Pasta Dept., Food Technology Research Institute, Agricultural Research Center.

2) Wheat Research Dept., Field Crop Research Institute, Agricultural Research Center.

\begin{abstract}
The effect of environmental temperatures on the production of wheat and the resulted bread quality of four cultivars was vestigated. The tested samples of (Misr 1, Gemmeiza 9, Sakha 93, and Sids 12) were grown under heat environment stress (HES) and compared with other samples of the same cultivars which were grown in the normal environment stress (NES). All wheat samples were milled in a Hummer mill to obtain $100 \%$ extraction rate whole meal flour. Rheological properties of all HES cultivars samples or NES were studied. The results appeared that heat stress increased water absorption, mixing time, arrival time and stability values of dough, while it decreased the dough weakening value. The same HES cultivars parameters showed an adverse tend. The extensograph results revealed that the HES cultivars recorded the highest elasticity compared with the NES cultivars. Extensibility of HES wheat bread cultivars recorded the lowest results compared with the NES wheat bread cultivars. The proportional umber of dough was increased in case of the HES cultivars compared with the NES cultivars. Energy value $\left(\mathrm{cm}^{2}\right)$ was increased in the HES cultivars, while it was decreased in the NES cultivars. Chemical analysis of whole wheat bread varieties appeared that the fat content was lower in the HES whole meal cultivars, whereas protein, ash and crude fiber of the HES cultivars recorded the highest percentage compared with the NES cultivars. Total carbohydrates of the NES cultivars recorded the highest percentage compared with the HES cultivar. Sensory evaluation attributes of balady bread which made from whole meal of all varieties were studied. The balady bread of HES cultivars recorded the highest acceptable degree compared with NES balady bread varieties. In general, balady bread made from whole meal flour of Misr 1 cultivar recorded the highest preference degree followed by balady bread of whole meal of Gemmeiza 9 cultivar and Sakha 93, respectively, while balady bread made from Sids 12 of HES cultivar showed the lowest acceptable degree.

Keywords: Bread wheat, rheological (farinograph and extensograph tests), chemical and sensory properties
\end{abstract}

\section{INTRODUCTION}

The understanding of the environment and complex interaction of genetic and environmental (GXE) factors is a highly essential issue to help breeders to set proper adjectives and strategies to develop wheat varieties to achieve the high yield potential as well as with specific and consistent quality 
attributes to meet market needs (Wiliams et al., 2008). The importance of the effects of genotype, environment and GXE is increasing for breeders, growers, grain traders and end-use processors. In wheat, environmental temperature affects grain yield, protein content and the size and number of starch granules (Sofield et al., 1977; Bhuller and Jenner 1985, Tester et al., 1995). Shi et al., (1994) reported that increasing the environmental temperature during grain filling led to increase the amylase content and, also, the starch gelatinization temperature was increased. Starches from most wheat grown at $40^{\circ} \mathrm{C}$ had increased portions of unit chains with DP 10-16 and reduced proportions of unit chains with DF 17-21. Two of the key enzymes in starch biosyenthesis, the starch synthase and branching enzyme, have been proposed to play a significant role in linking starch deposition when the temperature was exceeded than $25^{\circ} \mathrm{C}$ (Keeling et al., 1994). Variations in dough rheological properties are largely determined by the genotype $(G)$ but the environment $(\mathrm{E})$ and its interaction with $(\mathrm{G})$, also, play an important role in the expression of the end use product quality of a genotype (Peterson et al., 1998). Similary, Don et al., (2005) reported that the HMW-GS/LMW-GS ratio of glutenin macropolymer (GMP) decreased, but larger glutenin particles occurred under heat stress. Heat shock affects protein contents, SDS sedimentation volume and rheological properties (Corbellini et al., 1997 and Tahir et al., 2006). Bread wheat differs from durum wheat in kernel texture. In particular, common wheat cultivars can be divided into three endosperm texture classes based on their average SKCS (Single Kernel Characterization System) value. i.e. soft (SKCS index $=15-40$ ), medium hard (55-70) and hard (71-95). By contrast, all durum wheat cultivars are characterized by an external kernel texture with SKCS $>80$, mainly due to the absence of two proteins named puroindolines A (Pin-A) and B (Pin-B). Tryptophan-and cysteine rich polypeptides were, also, encoded by two closely linked genes named Pina-D1 and Pinb-D1, which are located in the distal end of the short arm of chromosome 5D (Gauteir et al., 1994 and Mattern et al., 1973). Soft textured common wheat cultivars possess wild-type allelers Pina-D1a and Pinb-D1a and accumulate large amounts of both Pin-A and Pin-B on the surface of their starch granules (Corona et al., 2001). The ratio between soluble and insoluble proteins, which affects bread-making quality is a function of the protein composition that is genetically controlled. Environmental factors, such as temperature, water and nitrogen also influence this ratio (Jia et al., 1996 and Stone and Nicolas, 1996). Bakery products are increasingly popular due to their ready-to-eat convenience, cost competitiveness, availability of various products with different taste and textural profiles, beneficial nutritional profile and longer shelf-life (Azziz et al., 2003). Among functional food additives, surfactants have been increased and used to improve bread quality. The beneficial effects of surfactants are due to the improvement in dough properties and quality of bread (Kamel and Ponte, 1993 and Potgieter, 1992). 


\section{MATERIALS AND METHODS}

HES bread wheat varieties, Misr1, Gemmeiza 9, Sakha 93, and Sids 12 as applied by Abo El-Naga and El-Gharbawy (2013), samples and other samples of the NES same varieties. All samples were milled in a Hummer mill to obtain whole meal flour (100\% extraction rate).

\section{Preparartion of balady bread:}

Balady bread formula was prepared by using $1000 \mathrm{~g}$ of whole meal flour (100\% extraction rate) as a base. The other ingredients were: $5 \mathrm{~g}$ active dry yeast, $10 \mathrm{~g}$ sodium chloride and $800-850 \mathrm{ml}$ water. The ingredients were mixed in a mixer for $25 \mathrm{~min}$. The resulted dough was left to ferment for one hour at $30^{\circ} \mathrm{C}$ and $85 \%$ relative humidity. After that, the dough was divided into $160 \mathrm{~g}$ pieces. The pieces were then arranged at a wooden board, previously sprinkled with a fine layer of bran, and left to ferment for about 45 min at $30^{\circ} \mathrm{C}$ and $85 \%$ relative humidity. The fermented dough pieces were flattened to form loaves and then baked at $450-500^{\circ} \mathrm{C}$ for $1.5 \mathrm{~min}$. The baked bread loaves were allowed to cool on wooden racks for $30 \mathrm{~min}$ at room temperature before evaluation and then packaged into polyethylene bags.

\section{Rheological properties:}

\section{Farinigraph tests:}

The farinograph tests were carried out by an OGH brabender farinograph instrument, Duisburg, Germany, to study the water hydration and mixing characteristsics of dough under investigation. The Water absorption $(\%)$, arrival time (min), dough development time (min), dough stability (min) and dough weakening (B.U) parameters as described in the AACC (2002).

\section{Extensograph test:}

Extensograph tests were carried out according to the method described in AACC (2002), using a 4821384 extensograph brabender Extensograph instrument, West Germany, to measure the dough elasticity(B.U), dough extensibility $(\mathrm{mm})$, dough prportional number (P.N., elasticity/ extensibility) and dough energy $\left(\mathrm{cm}^{2}\right)$.

Chemical composition of balady bread:

Chemical compositions (moisture, ether extract (fat), protein, crude fiber and ash contents) of balady bread were determined using the method outlined in AOAC (1990) and the carbohydrates were calculated by differences.

\section{Sensory evaluation of balady bread:}

Fresh samples of balady bread were sensory evaluated by 15 panelists from Food Technology Research Institute staff, Agricultural Research Center, Giza, Egypt. All the loave samples were characterized for external color, internal color, taste, odor and separation of layers. The characteristics were scored by 15, 10,20, 20 and 10 degrees, respectively, as recommended by Mousa et al., (1979).

\section{Statistically analyzed:}

Values of each sensory evaluated character were statistically analyzed. Such analysis was carried out by SPSS10 program (SPSS 2000) and Duncan's tests to specify the variation level at 0.05 . 


\section{RESULTS AND DISCUSSION}

Numerous researches were done to estimate the impact of different environmentl conditions on yield and its components. To achieve the objectives of such studies, it should evaluate the effect of such factors on the quality attributes of the produced bread. Therefore, the rheological, chemical and sensory properties of the bread manufactured by the tested varieties under the specified conditions, as applied by Abo El-Naga and El-Gharbawy (2013), were put under investigation in the present study.

Rheological properties:

The rheological (farinograph and extensograph measurements) properties of wheat bread varieties were recorded in Tables (1 and 2). These results appeared that, the HES (high temperature environment) recorded the highest values in relative to NES (agronomy under the normal weather) for each parameter, as discussed below:

Water absorption values showed that the HES varieties recorded the highest percentage of water absorption. While the NES varieties recorded the lowest percentage of water absorption (\%). It was, also, found that Misr 1 variety recorded the highest percentage (90.5\%) and followed by Gemmeiza $9(84 \%)$, while the values of the corresponding NES varieties recorded $82.5 \%$ and $82 \%$, respectively. These results may be due to the variation in protein percentage of the HES varieties as detected by Abo El-Naga and ElGharbawy (2013). These results are in agreement with those observed by Sofield et al., (1977) who reported that, environmental temperature variations affects grain yield, protein content and the size and number of wheat grains.

Table (1): Farinograph measurement values of bread wheat varieties cultivated under heat stress and normal conditions

\begin{tabular}{|l|l|c|c|c|c|c|}
\hline \multirow{3}{*}{ Conditions } & Variety & $\begin{array}{c}\text { Water } \\
\text { Absorption } \\
(\mathbf{\%})\end{array}$ & $\begin{array}{c}\text { Arrival } \\
\text { Time } \\
\text { (min) }\end{array}$ & $\begin{array}{c}\text { Dough } \\
\text { Development } \\
\text { (min) }\end{array}$ & $\begin{array}{c}\text { Stability } \\
\text { Time (min) }\end{array}$ & $\begin{array}{c}\text { Degree of } \\
\text { softening }\end{array}$ \\
\hline \multirow{4}{*}{ Heat stress } & Misr 1 & 90.5 & 2.5 & 3.5 & 14.0 & 20 \\
\cline { 2 - 7 } & Gemmeiza 9 & 84.0 & 1.0 & 1.5 & 11.0 & 50 \\
\cline { 2 - 7 } & Sakha 93 & 75.8 & 1.5 & 2.5 & 8.0 & 70 \\
\cline { 2 - 7 } & Sids 12 & 82.8 & 1.0 & 2.0 & 12.5 & 30 \\
\hline \multirow{3}{*}{ Normal } & Misr 1 & 82.5 & 1.0 & 2.0 & 6.5 & 70 \\
\cline { 2 - 7 } & Gemmeiza 9 & 82.0 & 0.5 & 1.0 & 9.5 & 60 \\
\cline { 2 - 7 } & Sakha 93 & 72.5 & 1.0 & 2.0 & 3.5 & 90 \\
\cline { 2 - 7 } & Sids 12 & 73.1 & 0.5 & 1.5 & 10.5 & 40 \\
\hline
\end{tabular}

HES Varieties rewarded the highest arrival time values compared the corresponding NES varieties. The values were ranged between 2.5 to 1.0 $\mathrm{min}$, while the NES varieties were ranged between 1.0 and $0.5 \mathrm{~min}$.

Dough development $(\mathrm{min})$ values were higher in HES varieties than the corresponding NES varieties. The NES varieties recorder 1.0, 1.5,2 and $2.0 \mathrm{~min}$ for Gemmeiza 9, Sids 12, Sakha 93 and Misr 1, respectively, while the corresponding values in the HES varieties were 1.5, 2.0, 2.5 and $3.5 \mathrm{~min}$, respectively. These results agreed with those found by Blumenthal et al., (1991) who reported that the environment (climate, soil, agronomic practices, 
etc.) exerts a softening influence on the expression of the technological quality of different cultivars. On the other hand Ciaffi et al., (1995) reported that, agronomy conditions, particularly marked in southern Europe where the Mediterranean climate characterized by increasing water deficit and thermal stress during grain filling may cause large fluctuations, not only on grain yield but also on grain protein content and composition, with higher effects on the rheological properties of dough.

The stability time (min) of HES varieties dough recorded the highest stability compared with the corresponding NES varieties. Misr 1 recorded the highest stability $(14.00 \mathrm{~min})$ followed by Sids 12 (12.5 min), while Sakha 93 recorded the lowest stability $(8.0 \mathrm{~min})$ value. On the other hand, NES varieties recorded the lowest stability (Sids 12 recorded $10.5 \mathrm{~min}$, followed by Gemmeiza 9 recorded 9.5 and Sakha 93 recorded the lowest stability which , $3.5 \mathrm{~min}$ ). These results are in agreement with those found by Daniel-Vazquez et al., (2012), who reported that, environment, that produced grain with higher protein content were not necessarily those of better rheological quality. Environments 14, 18 and 20 had the highest protein content, while environments 3,14 and 18 had the highest wet gluten percentage, both related with protein content. Environments with higher Alveograph and sedimentation volume were both 2007 Chilian C12 and 13), whilethose with higher farinograph stability were 4,7,16 and 17. On the other hand, Moldestad et al., (2011) found that, the temperature in different periods during grain filling had an impact on gluten resistance. In general, higher mean temperature from heading to approximately midway in the grain filling periods was positively related to gluten resistance. This was seen both for maximum and mean temperature. On the other hand, Uhlen et al., (2004) reported that the stronger gluten and higher SDS sedimentation volume in wheat were detected in the warmer seasons.

Degree of softening of wheat bread varieties increased with decreasing the stability of wheat bread dough (Table 1). All HES varieties recorded a lower (20-70) degree of softening than all other NES varieties (4090). Those results were concurrent with those found by Randall and Moss (1990) who reported an increment in dough strength with increasing mean temperature up to $30^{\circ} \mathrm{C}$. On the other hand, Johansson and Svensson (1998) analyzed field trials from southern parts of Sweden in the period of 1975 1996, and reported that weaker doughs was noticed in cooler seasons.

Table (2): Extensograph measurement values of bread wheat varieties cultivated under heat stress and normal conditions

\begin{tabular}{|c|l|c|c|c|c|}
\hline Conditions & \multicolumn{1}{|c|}{ Variety } & $\begin{array}{c}\text { Elasticity } \\
\text { (B.U) }\end{array}$ & $\begin{array}{c}\text { Extensibility } \\
(\mathbf{m m})\end{array}$ & PN & $\begin{array}{c}\text { Energy } \\
\left(\mathbf{c m}^{\mathbf{2}} \mathbf{)}\right.\end{array}$ \\
\hline \multirow{4}{*}{ Heat stress } & Misr 1 & 530 & 45 & 11.8 & 16 \\
\cline { 2 - 6 } & Gemmeiza 9 & 360 & 52 & 6.9 & 20 \\
\cline { 2 - 6 } & Sakha 93 & 340 & 35 & 9.7 & 17 \\
\cline { 2 - 6 } & Sids 12 & 340 & 42 & 8.1 & 19 \\
\hline \multirow{5}{*}{ Normal } & Misr 1 & 230 & 58 & 3.9 & 22 \\
\cline { 2 - 6 } & Gemmeiza 9 & 260 & 90 & 2.9 & 27 \\
\cline { 2 - 6 } & Sakha 93 & 225 & 69 & 3.3 & 29 \\
\cline { 2 - 6 } & Sids 12 & 220 & 107 & 2.1 & 37 \\
\hline
\end{tabular}


Extensograph measurement results shown in Table (2) appeared that, all parameters (Elasticity (B.U), extensibility ( $\mathrm{min}), \mathrm{PN}$ and Energy $\left(\mathrm{cm}^{2}\right)$ of all HES varieties recorded rheological measurement values better than all corresponding NES varieties. Elasticity (B.U) in HES varieties under recorded the highest elasticity compared with all NES varieties. Misr 1 recorded the highest elasticity (530 BU) followed by Gemmeiza 9 (360 BU), Sakha 93 and Sids 12 (both of them recorded $340 \mathrm{BU}$ ).

Extensibility of all HES varieties recorded the lowest values compared with the corresponding NES varieties. Extensibility of Gemmeiza 9 recorded the highest extensibility $(52 \mathrm{~mm})$ followed by Misr $1(45 \mathrm{~mm})$ and Sakha 93 which recorded the lowest extensibility $(35 \mathrm{~mm})$. The NES varieties recorded the highest extensibility (ranged from 58-107mm) and Sids 12 recorded the highest extensibility $(107 \mathrm{~mm})$ followed by Gemmeiza $9(90 \mathrm{~mm})$ and the lowest results was found in Misr $1(58 \mathrm{~mm})$. These results agreed with those reported by Johansson and Svensson (1998) and Uhlen et al., (2004) as previously discussed.

The proportional number (elasticity/extensibility) of dough was higher in HES varieties compared with values of NES varieties. Misr1 recorded the highest values (11.8) followed by Sakha 93 (9.7) and the lowest value was in Gemmeiza 9 (6.9). The NES varieties recorded the lowest results of proportional number values, where, Misr 1 recorded 3.9 followed by Sakha 93 (3.3), while Sids 12 recorded the lowest value (2.1).

Energy value $\left(\mathrm{cm}^{2}\right)$ of the tested dough of HES varieties recorded the lowest values compared with the dough of the NES varieties. The Misr 1 variety under heat stress recorded the lowest energy value (16), followed by Sakha 93 (17) while Gemmeiza 9 recorded the highest energy (20) value. On contrary, the Sids 12 NES variety recorded the highest energy (37) value, followed by Sakha 93 (29), Gemmeiz 9 (27) and Misr 1 which recorded the lowest energy value $\left(22 \mathrm{~cm}^{2}\right)$.

\section{Chemical compositions of whole-meal flour:}

Moisture content of the HES tested varieties recorded lowest values than the corresponding NES varieties (Table 3). Protein and fat contents showed the same trend of moisture, where the HES varieties recorded the lowest fat content compared with the corresponding NES varieties. These results are in agreement with those found by Panozzo and Eagles (1999) who reported that, chronic moderate $\mathrm{HT}\left(25-35^{\circ} \mathrm{C}\right)$ and short periods of vary than $\mathrm{HT}\left(>35^{\circ} \mathrm{C}\right)$ during the filling phase and are frequently associated with an increase in grain protein concentration and a decrease in final grain dry mass and hence grain yield. Sofield et al., (1977); Bhuller and Jenner (1985); Tester et al., (1995), also, reported that environmental temperature affect the amylose content, structural features and gelatinization properties of starches in several cereal species. In wheat, environmental temperature affects grain yield, protein content, and the size and number of starch granules. The ash and crude fiber contents of the HES varieties recorded the highest percentage of ash compared with the corresponding NES varieties. On contrary, total carbohydrates of HES varieties recorded the lowest values compared with corresponding NES varieties. These observations are concurrent with those found by Jenner et al., (1991) who reported that, the 
effects are mostly simply explained by the effects of temperature on the rate and duration of grain filling and by the reduction of starch.

Table (3): Chemical compositions (\%) of bread wheat varieties cultivated under heat stress and normal conditions

\begin{tabular}{|c|c|c|c|c|c|c|c|}
\hline Conditions & Variety & Moisture & Fat $^{*}$ & Protein ${ }^{*}$ & Ash $^{*}$ & $\begin{array}{l}\text { Crude } \\
\text { fiber* }\end{array}$ & Carbohydrates ${ }^{\star}$ \\
\hline \multirow{4}{*}{ Heat stress } & Misr 1 & 7.62 & 0.65 & 11.55 & 1.59 & 1.72 & 84.49 \\
\hline & Gemmeiza 9 & 5.75 & 0.88 & 10.82 & 1.34 & 1.89 & 85.07 \\
\hline & Sakha 93 & 8.50 & 0.177 & 12.45 & 1.56 & 1.80 & 84.01 \\
\hline & Sids 12 & 7.08 & 0.74 & 13.54 & 1.63 & 1.91 & 82.18 \\
\hline \multirow{4}{*}{ Normal } & Misr 1 & 9.50 & 0.80 & 10.14 & 1.01 & 1.34 & 86.71 \\
\hline & Gemmeiza 9 & 9.98 & 1.15 & 10.78 & 1.30 & 1.61 & 85.16 \\
\hline & Sakha 93 & 9.10 & 1.5 & 8.45 & 1.53 & 1.70 & 86.82 \\
\hline & \begin{tabular}{|l|} 
Sids 12 \\
\end{tabular} & 8.60 & 1.05 & 7.95 & 1.60 & 1.87 & 87.53 \\
\hline
\end{tabular}

\section{Sensory Evaluation:}

Sensory evaluation of balady bread made from HES whole meal wheat (Misr 1, Sids 12, Gemmeiza 9 and Sakha 3) and the same NES varieties after baking and cooling at room temperature was found in Table (4). The panelists evaluated the external color, internal color, taste, odor, and separation of the two layers of bread.

Table (4): Sensory attribute values of bread prepared by wheat varieties cultivated under heat stress and normal conditions

\begin{tabular}{|c|c|c|c|c|c|c|}
\hline Conditions & Variety & $\begin{array}{c}\text { External } \\
\text { color }\end{array}$ & $\begin{array}{l}\text { Internal } \\
\text { color }\end{array}$ & Taste & Odor & $\begin{array}{c}\text { Separation of } \\
\text { layers }\end{array}$ \\
\hline \multirow{4}{*}{ Heat stress } & Misr 1 & $\begin{array}{r}14.80 \mathrm{a} \\
\pm 0.4216 \\
\pm 0.1333\end{array}$ & $\begin{array}{c}9.10 \mathrm{a} \\
\pm 0.7378 \\
\pm 0.2333\end{array}$ & $\begin{array}{c}18.50^{\mathrm{a}} \\
\pm 0.5270 \\
\pm 0.1666\end{array}$ & $\begin{array}{c}18.50^{a} \\
\pm 0.5270 \\
\pm 0.1666\end{array}$ & $\begin{array}{c}8.90^{\mathrm{a}} \\
\pm 0.3162 \\
\pm 0.1000\end{array}$ \\
\hline & Gemmeiza 9 & $\begin{array}{c}14.10^{\mathrm{b}} \\
\pm 0.3162 \\
\pm 0.1000\end{array}$ & $\begin{array}{c}8.40^{\mathrm{b}} \\
\pm 0.6992 \\
\pm 0.2212\end{array}$ & $\begin{array}{c}17.70^{\mathrm{b}} \\
\pm 0.4880 \\
\pm 0.1522\end{array}$ & $\begin{array}{l}17.70^{\text {ab }} \\
\pm 0.6719 \\
\pm 0.2134\end{array}$ & $\begin{array}{c}7.90^{b} \\
\pm 0.3162 \\
\pm 0.1000\end{array}$ \\
\hline & Sakha 93 & $\begin{array}{r}13.60^{\mathrm{c}} \\
\pm 0.5164 \\
\pm 0.1633\end{array}$ & $\begin{array}{c}7.80^{\mathrm{cd}} \\
\pm 0.6124 \\
\pm 0.2000\end{array}$ & $\begin{array}{c}17.10^{c} \\
\pm 0.3152 \\
\pm 0.1000\end{array}$ & $\begin{array}{l}16.80 \text { abc } \\
\pm 0.7388 \\
\pm 0.2494\end{array}$ & $\begin{array}{c}7.50^{\mathrm{b}} \\
\pm 0.5220 \\
\pm 0.1657\end{array}$ \\
\hline & Sids 12 & $\begin{array}{c}12.80^{d} \\
\pm 0.7888 \\
\pm 0.2494 \\
\end{array}$ & $\begin{array}{c}7.50^{\text {ed }} \\
\pm 0.5270 \\
\pm 0 . \pm 0.1667\end{array}$ & $\begin{array}{l}16.00^{\text {ed }} \\
\pm 0.6714 \\
\pm 0.1491\end{array}$ & $\begin{array}{l}16.00 \text { bcd } \\
\pm 0.6619 \\
\pm 0.2108 \\
\end{array}$ & $\begin{array}{c}6.96{ }^{d c} \\
\pm 0.5676 \\
\pm 0.1795\end{array}$ \\
\hline \multirow{4}{*}{ Normal } & Misr 1 & $\begin{array}{r}13.50^{c} \\
\pm 0.5270 \\
\pm 0.1667 \\
\end{array}$ & $\begin{array}{c}8.10^{\mathrm{cb}} \\
\pm 0.3162 \\
\pm 0.1000 \\
\end{array}$ & $\begin{array}{c}17.20^{\circ} \\
\pm 0.4216 \\
\pm 0.1333 \\
\end{array}$ & $\begin{array}{l}16.30^{\text {bcd }} \\
\pm 2.9458 \\
\pm 0.9315 \\
\end{array}$ & $\begin{array}{c} \pm 7.80^{\mathrm{b}} \\
\pm 0.4216\end{array}$ \\
\hline & Gemmeiza 9 & $\begin{array}{c}12.80^{c} \\
\pm 0.6325 \\
\pm 0.2000\end{array}$ & $\begin{array}{c}7.80^{\mathrm{cd}} \\
\pm 0.6325 \\
\pm 0.2000\end{array}$ & $\begin{array}{c}16.30^{d} \\
\pm 0.4830 \\
\pm 0.1528\end{array}$ & $\begin{array}{l}15.40 \text { edc } \\
\pm 2.9889 \\
\pm 0.9452\end{array}$ & $\begin{array}{c}7.00^{c} \\
\pm 0.4714 \\
\pm 0.1491\end{array}$ \\
\hline & Sakha 93 & $\begin{array}{r}12.20^{\mathrm{e}} \\
\pm 0.6325 \\
\pm 0.2000\end{array}$ & $\begin{array}{c}7.20^{\mathrm{e}} \\
\pm 0.6325 \\
\pm 0.2000\end{array}$ & $\begin{array}{c}15.70^{\mathrm{e}} \\
\pm 0.6209 \\
\pm 0.2134\end{array}$ & $\begin{array}{l}14.70^{\mathrm{ed}} \\
\pm 2.6967 \\
\pm 0.8825\end{array}$ & $\begin{array}{l}6.50 d \\
\pm 0.5766 \\
\pm 0.1667\end{array}$ \\
\hline & Sids 12 & $\begin{array}{c}11.40^{f} \\
\pm 0.5164 \\
\pm 0.1633 \\
\end{array}$ & $\begin{array}{c}6.60^{f} \\
\pm 0.5164 \\
\pm 0.1633 \\
\end{array}$ & $\begin{array}{c}14.60^{f} \\
\pm 0.6902 \\
\pm 0.2211 \\
\end{array}$ & $\begin{array}{c}13.90^{\mathrm{e}} \\
\pm 2.0461 \\
\pm 0.9000 \\
\end{array}$ & $\begin{array}{l}5.80 \quad \mathrm{e} \\
\pm 0.7166 \\
\pm 0.1333 \\
\end{array}$ \\
\hline
\end{tabular}

- Each mean within the same column followed by the same letter is not significant different at 0.05 level.

- Each mean is followed by \pm standard deviation and \pm standard error, respectively. 
Concerning the external color of balady bread, a significant differences were noticed among the samples. Balady bread made from whole wheat bread Misr 1 recorded the highest values followed by Gemmeiza 9 , Sakha 93 and Sids 12, respectively. While the bread made from whole wheat flour of NES varieties recorded the lowest degree compared with the corresponding bread which were made from whole wheat flour of HES varieties. The preferred degree was sorted as Misr 1, Gemmeiza 9, Sakha 93 and Sids 12, respectively.

The internal color of balady bread made from whole wheat flour of HES varieties recorded the highest degree compared with the bread made from whole wheat flour of the corresponding NES varieties. In both, Misr 1 varieties group (normal or heat) recorded the highest degree compared with the bread made by the other varieties. The other varieties, in both of HES or NES, Gemmeiza 9, Sakha 93 and Sids 12 were gradually reversed in the preferred degree of taste, color and separation of layers attributes. These results agreed with Shewry et al. (2002) and Don et al. (2006) who reported that, the end-use quality of a wheat cultivar depends on the combination and interaction of several compositional traits; however, the unique viscoelasticity of wheat gluten is the main compositional factor determining if wheat dough is suitable to manufacture breads, noodles, biscuits, or cakes. High molecular weight glutenin subunits (HMW-GS) play a critical role in determining dough elasticity. On the other hand Caffe-Terenl et al., (2011) found that, yeast type represented the main source of variations of several protein quality characteristics.

Consequently, it could be concluded that environment may be the main source of variations in protein, ash contents and some dough strength related properties (e.g. bread volume, absorption and dough extensibility values). On the other hand, Misr 1 could be considered the proper variety, due to its stability toward either SHE or NHE conditions and its ability to produce a highly nutritional and preferred bread.

\section{REFERENCES}

AACC (2002). Approved Method of American Association of Cereal Chemists. Published. by American Association of Cereal Chemists. St. Paul, USA.

Abo El-Naga M. M. and M.M. El-Gharbawy Hoda (2013). Effect of wheat varieties and environmental temperatures on wheat production and bread characteristics: 1- Effect of environmental temperatures on yield and its components. J. Agric. Sci. Mansoura Univ., (In press).

AOAC (1990). Official Methods of Analysis. 15th $\mathrm{ed}$, Association of Official Analytical Chemists . Arlington, Virginia 22201, USA.

Azizi M.H., N. Rayabzadekand E. Riahi (2003). Effect of storage of surfactant gels on the bread making quality of wheat flour. Food Chem., 89:133138. 
Bhuller S. S. and C. F. Jenner (1985). Different responses to high temperature of starch and nitrogen accumulation in the grain of four cultivars of wheat. Aus. J. Plant Physiol., 12:363-375.

Blumenthal C. S., L.L. Batey, F. Bekes, C.W. Wrigley, and E.W.R. Barlow (1991). Seasonal changes in wheat grain quality associated with high temperature during grain filling. Aus. Agric. Res., 42:21-30.

Caffe-Trenl M., K.D. Glover, P.G. Krishanan, G.A. Hareland, K.D. Bondalapti and J. Stein (2011). Effect of wheat genotype and environment on relationships between dough extensibility and breadmaking quality. Cereal Chem., 88:201-208.

Ciaffi M., L. Tozz, B. Borghi, M. Carbellini and D. Larfiandra (1995). Effect of heat shock during grain filling on gluten protein composition of bread wheat. J. Cereal Sci., (in press).

Corbellini M., M.G. Canevar, L. Mazza, M. Ciaffi, D. Lafiandra and B. Broghi (1997). Effect of the duration and intensity of heat shock during grain filling on dry matter and protein accumulation, technological quality and protein composition in bred and durum wheat. Functional Plant Biology, 24:245-260.

Corona V., L. Gazza, G. Boggini and N.E. Pogna (2001). Variation in friabilin composition as determined by A-PAGE fractionation and PCR amplification and its relationship to grain hardness in bread wheat. Journal of Cereal Science, 34: 243-250.

Daniel Vazquez, G. Andres, Berger, M. Cunbertib, C. Bainott, M. Zavariz, D. Miranda, P. Scheeren, C. Jobet, J. Zuniga, G. Cabrara, R. Verges and R.J. Pena (2012). Influence of cultivar and environment on quality of Latin American wheat. J. Cereal Sci., 56:196-203.

Don C., G. Lookhart, H. Nasem, F. Macritchie and R.J. Hamer (2005). Heat stress and genotype affect the glutenin particles of the glutnin macropolymer-gel fraction. $\mathrm{J}$ of Cereal Science, 42:69-80.

Don, C.; Mann, G.; Bekes, F. and Hammer, R. J. (2006). HMW-GS appect the properties of glutenin particles in GMP and thus flour quality. J. Cereal Sci., 44:127-136.

Gautier M.F., M.E. Aleman, A. Guirao, D. Marion and P. Joudrier (1994). Triticum aestivum puroindolines, two basic cysteine-rich seed protein DNA analysis and developmental gene expression. Plant Molecular Biology, 25:43-57.

Jenner C.F., T. D. Ugalde and D. Aspinall (1991). The physiology of starch and protein deposition in the endosperm of wheat. Aus. J. Plant Physiol., 18: 211-226.

Jia Y. E., J.L. Faber and T. Aussenac (1996). Effect of growing location on response of protein polymerization to increased nitrogen fertilization for the common wheat cultivar Soissons: relationship with some aspects of the breadmaking quality. Cereal chem., 73: 526-532.

Johansson E. and G. Svensson (1998). Variation in bread-making quality: effects of weather parameters on protein concentration and quality in some Swedish wheat cultivars grown during the period 1975-1996. J. Sci. Food Agric., 78(1):109-118. 
Kamel B.S. and J.T. Ponte (1993). Mulsifiers in baking. In: Kamel, B. S. and Stauffer (Eds). Advances in baking Technology. Blackie cademic nd professional, Bishopsbriggs. Glasgow, U. K., pp, 179-222.

Keeling P.L., R. Banisardr, L. Barone, B.P. Wasserman and G.W. Singletary (1994). Effect of temperature on enzymes in the pathway of starch biosynthesis in developing whet and maize grain. Aust. J. Plant Physiol., 21:807-827.

Mattern P.Y., R. Morris, Y.W. Schnidt and V.A. Jhonson (1973). Location of genes for kernel properties in wheat varieties cheynne and chromosome substitution lines, In: sears, E.R., Sears, L.M.S. (eds), proceedings of the 1st international wheat genetics symposium. University of Missouri Press, Columbia, M.O., USA, pp 703-707.

Moldestad A., M.F. Ellen, H. Bernt and O.S. Arn (2011). Effect of temperature variations during grain filling on wheat gluten resistance. J. Cereal Sci., 53: 347-354.

Mousa E.L, R.H. Ibrhim, W.C. Shuvey and R.D. Maneval (1979). Influence of wheat classes, flour extractions and baking methods on Egyptian balady bread. Cereal Chem., 56(6):563-566.

Panozzo J.F. and H.A. Eagles (1999). Rate and duration of grain filling and grain nitrogen accumulation of wheat cultivars grown in different environments. Aus. J. Agric. Res., 50:1007-1015.

Peterson C.J., R.A. Graybosch, D.R. Shelton and P.S. Baenziger (1998). Baking quality of hard winter wheat response of cultivars to environment in the Great Plains. Euphytica, 100: 157-162.

Potgieter J. (1992). Emulsifiers for bakery. Food Reviews, 18(6):23-25.

Randall J. and H.J. Moss (1990). Some effects of temperature regime during grain filling on wheat quality. Aus. J. Agric. Res., 41(4):603-617.

Shewry P.R., N.G. Halford, P.S. Belton and A.S. Tathan (2002). The structure and properties of gluten: an elastic protein from wheat grainphilosophical transaction of the royal society. B: 133-142.

Shi Y.C., P.A. Seib and J.E. Bernardin (1994). Effect of temperature during grain-filling on starches from six wheat varieties. Cereal Chem., 71: 369-383.

Sofield I., L.T. Ivans, M.G. Cook and I.F. Wardlaw (1977). Factors influencing the rate and duration of grain filling in wheat. Aus. J. Plant Physiol., 4:785-797.

SPSS (2000). Statistical Package for Social Sciences. SPSS for Windows, Version 10, SPSS Inc., Chicago, IL, USA.

Stone P.J. and M.F. Nicolas (1996). Effect of timing of heat stress during grain filling on two wheat varieties differing in heat tolerance. II. Fractional protein accumulation. Aus. J. Plant Physiol. , 23: 739-749.

Tahir L.S.A., N. Nakata, A.M. Ali, H.M. Mustafa, A.S.IL. Saad, K. Takata, N. Ishikawa and O. S. Abdalla (2006). Genotype and temperature effects on wheat grain yield and quality in a hot irrigated environment. Plant Breeding, 125: 323-330. 
Tester R.F., W.R. Morrison, R.H. Ellis, J.R. Piggoh, G.R.Batts, T.R. Wheeler, J.I.L. Morrison, P. Hadley and D.A. Ldwards (1995). Effects of elevated growth temperature and carbon dioxide levels on some physiochemical properties of wheat starch. J. Cereal. Sci., 22:63-71.

Uhlen A.K., S. Sahstrom, E.M. Magnus, E.M. Fargestad, J.A. Dieseth and K. Ringlund (2004). Influence of genotype and protein content on the baking quality of hearth bread. J.Sci. Food. Agric., 8:887-894.

Williams R.M., L. Obrien, H.A. Eagles, V.A. Solah and V. Jayasena (2008). The influences of genotype environment and genotype environment interaction on wheat quality. Australian Journal of Agricultural Research, 59: 95-111.

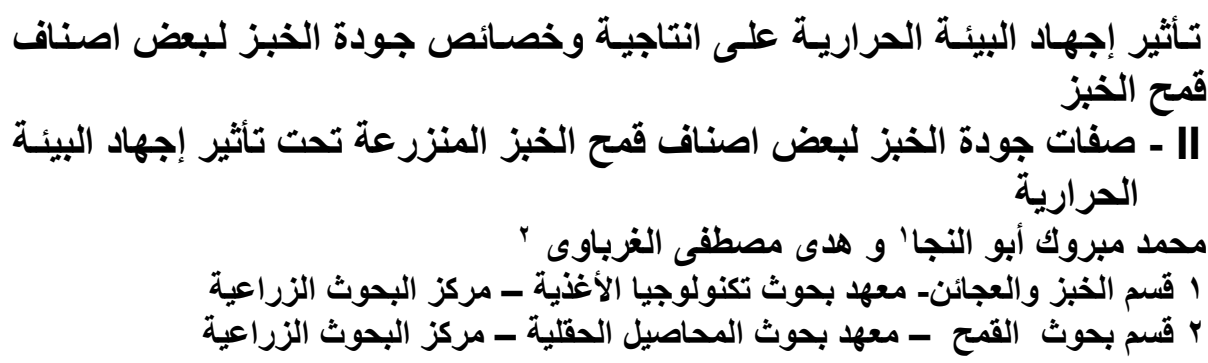

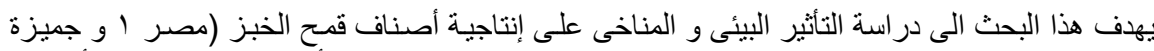

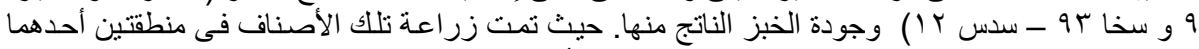

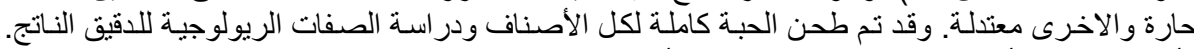

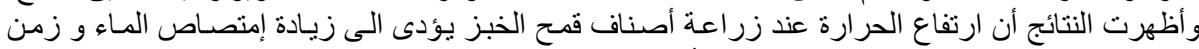

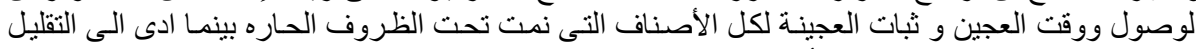

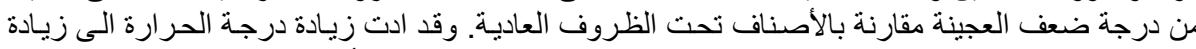

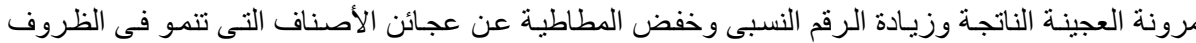

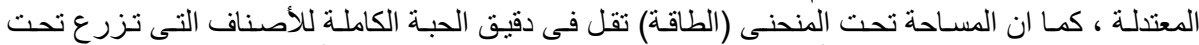

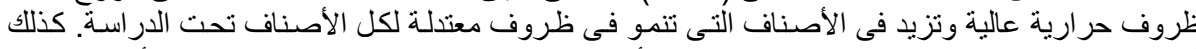

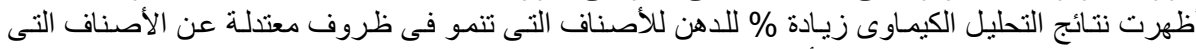

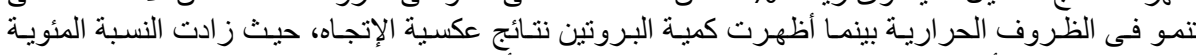

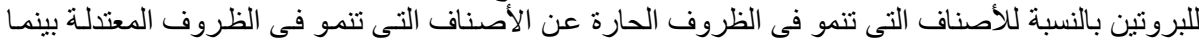

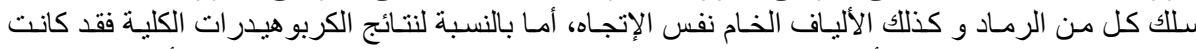

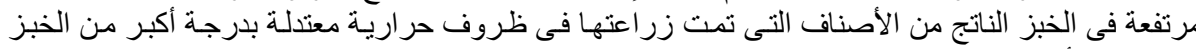

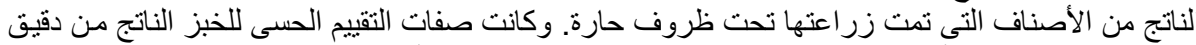

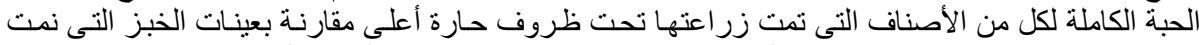

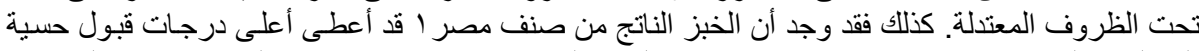

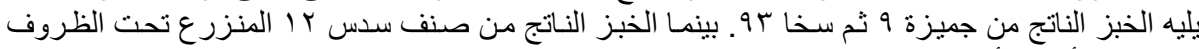
المعتلة قد أعطى أدنى درجات قى الصفات التى تمت دراستها.

كلية الزراعة - جامعة المنصورة مركز البحوث الزراعية
قام بتحكيم البحث

أ.د / أدادل عبد الجواد سلامهـ أ.د / محمود عبد الله صالح عاد عله 